\title{
Biophysical and econometric analysis of adoption of soil and water conservation techniques in the semiarid region of Sidi Bouzid (Central Tunisia)
}

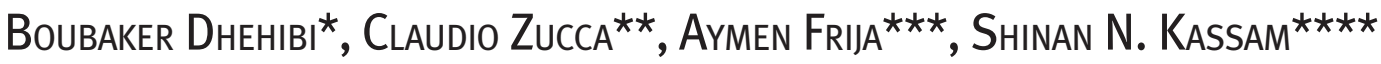

DOI: $10.30682 / \mathrm{nm} 1802 \mathrm{~b}$

JEL codes: Q24, Q25, C25

\begin{abstract}
Soil and water conservation technologies (SWCT) are important to farmers, to the research community, as well as to the policy makers, given that declining soil health, and increasing erosion and moisture stress have implications for agricultural livelihoods, national food security, and more generally for wellbeing within rural communities. Yet, despite Tunisia was at forefront of introducing them, the uptake of SWCT by farmers has been less broad than desired. This study aims to identify and analyze those factors that have affected the rate of adoption of SWCT within the Sidi Bouzid governorate of Central Tunisia; a region that is representative of resource-poor environments within the country, and one where land degradation is of both historical and contemporary concern. Employing a binary logistic regression model, with data obtained from a survey of 250 farmers, our results suggest that socio-economic and institutional factors play an important role in the adoption of SWCT. Membership within an agricultural cooperative was positively correlated with adoption. Surprisingly, however, participation in organized trainings for SWCT was negatively correlated with adoption, similarly to livestock holdings. We provide plausible explanations for this counterintuitive finding, together with an argument that conventional processes for knowledge transfer and dissemination are in need of reform.
\end{abstract}

Keywords: Soil and water conservation, Physical conservation, Biological conservation, Logistic regression, Tunisia.

\section{Introduction}

Land degradation is a major challenge to effective agricultural production within dry land areas. This is especially true for countries such as Tunisia where land degradation has been of signif- icant historical and contemporary concern (FAO, 2011), and is a constraint to the sustainability of rain-fed agricultural production within rural communities (CNEA, 2008). Recent estimates suggest that the livelihood of $35 \%$ of the popula-

\footnotetext{
* Resilient Agricultural Livelihood Systems Program (RALSP), International Center for Agricultural Research in the Dry Areas (ICARDA), Amman, Jordan.

** Integrated Land and Water Management Program (ILWMP), International Center for Agricultural Research in the Dry Areas (ICARDA), North-Africa Platform, Rabat, Morocco.

*** Resilient Agricultural Livelihood Systems Program (RALSP), International Center for Agricultural Research in the Dry Areas (ICARDA), Tunis, Tunisia.

**** Caritas Switzerland, Tajikistan.

Corresponding author: b.dhehibi@cgiar.org.
} 
tion is dependent on the agricultural sector. Economic development within rural areas depends therefore on the performance of the agricultural sector, and this in turn depends on the sustainable and efficient use of the natural resource base.

Estimates indicate that $52 \%$ of Tunisia's agricultural land base is affected by severe water erosion processes (CNEA, 2008), and that the storage capacity of large water reservoirs is decreasing by $0.8 \%$ annually due to siltation. The same study highlights that the highland steppe ecoregion ("Haute Steppe") is by far the most sensitive area to desertification within the northern and central parts of the country, with $60 \%$ of the land area (approximately 754,700 ha) considered to be strongly degraded. In this region, and particularly within the Sidi Bouzid Governorate, the degradation of natural resources is argued to be the main threat to the productivity of agro-pastoral systems. For this reason, soil and water conservation is a central element of local development strategies (CNEA, 2007).

Soil and water conservation technologies (SWCT) are of continued and pressing interest to researchers and policy makers given that agricultural productivity, and thereby food security, are seriously threatened by a steady decline in soil health and increasing soil moisture stress (Marquez et al., 2016). Specialized institutions in Tunisia have extensively promoted SWCT since the 1990s (Ministry of Agriculture, 2014), to reduce surface runoff, enhance groundwater recharge, reduce rainwater losses, and mitigate soil erosion. SWC interventions were extensively implemented within the country since the 1950s (Heusch, 1986; Roose et al., 2012); yet, their achievements have fallen below expectations (Roose et al., 2012). In fact, despite a considerable environmental success, obtained through large scale initiatives promoted by the central government, uptake by farmers has been less broad than desired. In general, poor adoption rates of agricultural innovations can be ascribed to many reasons such as political, institutional, economic, financial, and technical factors (Cooly and Linn, 2014), but the case of SWCT innovations is slightly different. For this type of technologies, the adoption causality is not well identified, and it is likely to be strongly linked to contextual factors. Notwithstanding the social and cultural considerations affecting the farmers' decision to adopt, the introduction of economic incentives targeting SWCT should be considered as a priority, especially in the context of the environmentally sensitive areas of Tunisia, such as within the region of Sidi Bouzid.

The adoption of improved SWCT practices within developing countries has attracted much attention from the research community, scientists and policy makers mainly because land degradation is a key challenge for agricultural production (De Graaff et al., 2008). De Graaff et al. (2008) have outlined three phases in the adoption process of certain SWCT measures: (i) the acceptance phase; (ii) the actual adoption phase, and (iii) the final adoption phase. The first phase of acceptance includes awareness, evaluation and trial, all of which combined lead to the initiation of investment. The actual adoption phase is characterized by efforts or investments made to implement the initial measures at a broader scale compared to that of a trial (typically the farm plot level). The last and third phase, final adoption, is the stage within which the existing SWCT measures are maintained over many years and spread over fields (with same agro-ecological context) through the demonstration of the outcomes attained.

Previous research studies conducted in different areas of Tunisia indicate that different individual, economic, social, institutional and biophysical characteristics have influential roles in farmers' decisions related to the adoption of SWCT technologies (Hudson, 1993; Achouri, 1995; Bachta, 1995; Sghaier et al., 2002; Ouessar et al., 2006; König et al., 2012). An appropriate understanding of these factors in Central Tunisia would assist in the formulation and implementation of more effective policy interventions designed to enhance the widespread adoption of these technologies. This would be strategic, considering that this region is particularly vulnerable to soil erosion, and therefore requires effective interventions. Such evaluation should also take into consideration local farmers' aspirations, capacities, and economic conditions as they are ultimately the final adopters of SWCT technologies. 
The purpose of this research is, therefore, to contribute to the understanding of those factors influencing farmers' decisions regarding the adoption of SWCT within the Sidi Bouzid study area. We identify socio-economic, institutional and biophysical factors that are likely to influence farmers' participation in and adoption of those conservation activities and we evaluate the strength of correlation between adoption and the identified influential factors. Thereafter, we provide a set of explanations for why farmers within the study area appear hesitant in the use of SWCT.

The analysis is likely to be in a beneficial value in increasing the understanding of the adoption and dissemination of SWC practices, specifically within the study area, and generally contributing to the existing knowledge related to the diffusion and widespread of these practices in rural Tunisia. In addition, conclusions and recommendations from this research paper will, certainly, contribute to identify and boost the policy and regulatory measures that could foster greater and faster adoption of such technologies leading to improve effectiveness and efficiency of agricultural extension strategies, and consequently increasing farmer's well-being within rural communities

\section{Literature review and theoretical frame- work}

Economic, cultural, and social factors, together with constraints in terms of natural resources, affect the speed at which farmers adopt new technologies (Lapar et al., 1999; Soule et al., 2000). Conceptually, the analysis of SWCT adoption within this study considers four main types of drivers for SWCT adoption: i) socio-demographic factors, ii) structural variables related to the farm and other operational capacities, iii) access to capital markets, and iv) participation and collective action (see Figure 1).

Socio-demographic factors. The decision to adopt a new technology may be undertaken on the basis of an assessment of the relative profitability and the risks associated with adoption, among others. The way farmers perceive such risk and utility will differ, depending on their own cognitive capacities which are in turn influ- enced by a set of sociodemographic attributes. Age, for example, can positively or negatively affect the adoption of conservative measures (Bekele and Drake, 2003). Age, associated with long years of experience in agriculture, could positively influence the decision to adopt. Relatively older farmers are also likely to have an advantage of more flexibility in access to credit, and are likely more aware of the environmental benefits of conservation practices (BaumgartGetz et al., 2012). Education is often argued as a variable that influences rates of adoption (Alcon et al., 2011). Finally, land tenure arrangements could affect the adoption of best management practices, yet the effect remains ambiguous (Khanna et al., 1999).

Structural variables are equally important determinants for adoption of SWCT. Farm size is thought to play a relevant role in the effectiveness of 'best' management practices. Large agricultural holdings do have better capacities to invest in new technologies, thereby allowing increasing returns to scale (Robinson and Napier, 2002). Farms located in more marginal areas (steep slopes) are more concerned with adopting conservation practices that mitigate problems of erosion (Bekele and Drake, 2003). In the literature, the adoption of an innovative technique, such as conservation practices, has been found to be influenced by farmers' preferences and attitudes towards environmental preservation (Menozzi et al., 2014), which is related to the expected depreciation of the land value due to degradation. On the other hand, poor soil quality can impede farmers to adopt conservation practices, which may potentially jeopardize the viability of agricultural systems given that farmers may not expect improvement of productivity (Jara-Rojas et al., 2013). Baumgart-Getz et al. (2012) suggest that the adoption decision is a result of an interaction of agronomic, social, economic and environmental factors. Among structural drivers, we particularly recognize the importance of considering land fragmentation as an important factor that may facilitate or hinder the decision to invest in SWCT practices. The existence of family labor and the range of agricultural activities undertaken at the farm level are also important structural drivers that may 


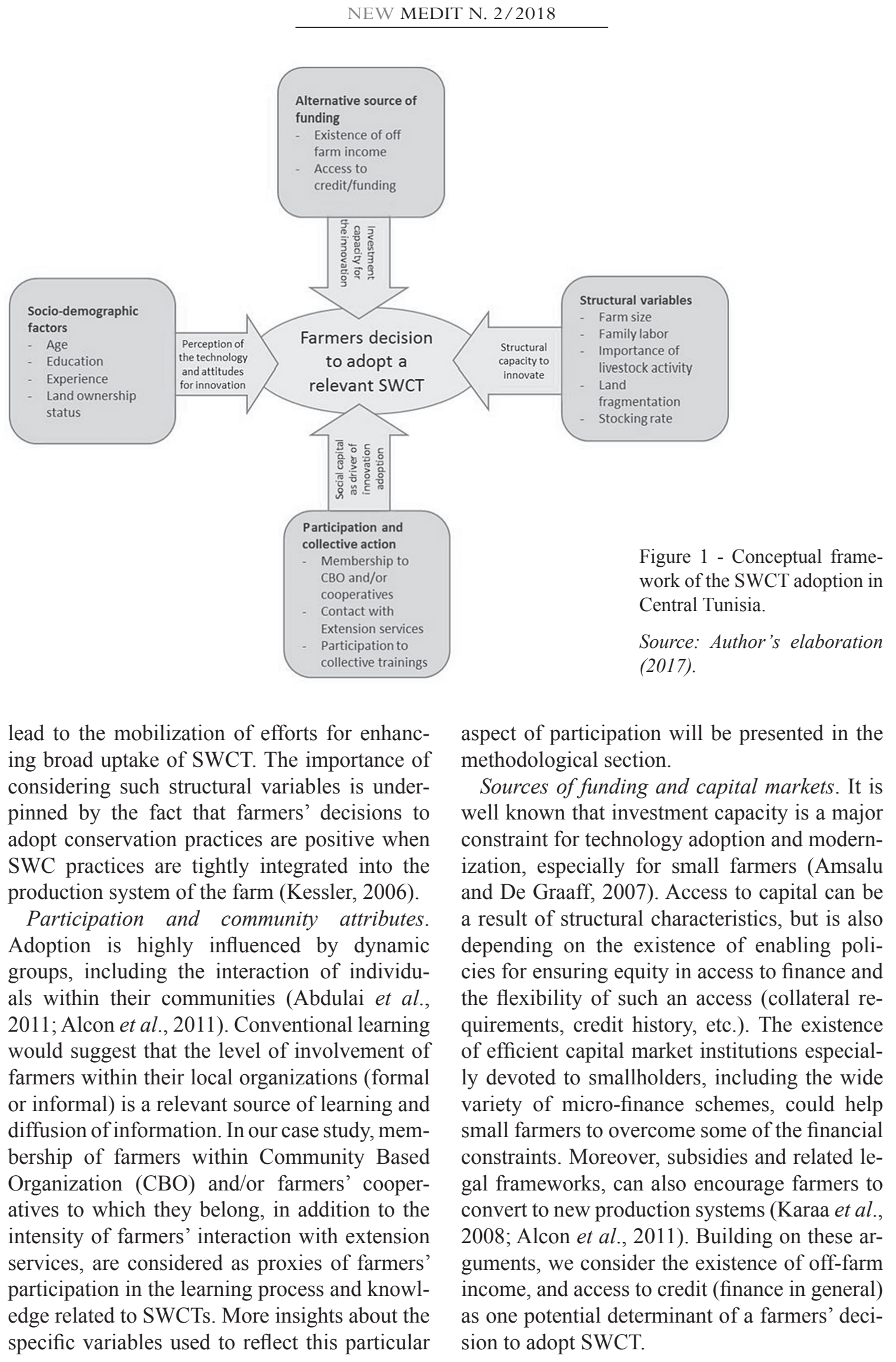




\section{Soil and water conservation techniques in the study area}

As mentioned above, soil and water conservation is a key element of the developmental strategy for central Tunisia, and particularly for the Haute Steppe ecological region, given its high vulnerability to soil erosion. Technical literature highlights the efforts undertaken by local governmental bodies to design and plan SWC interventions, which year after year continue to be ranked as first among agricultural development priorities (e.g.: CNEA-CRDA Sidi Bouzid, 1994; CRDA Sidi Bouzid, 2003; MEHAT, 2009). The interventions undertaken to date include the implementation of SWC measures based on the construction of physical structures, as well as the dissemination of "soft" techniques that are inspired by the principles of conservation agriculture, such as reduced tillage, mulching, green manuring, strip and contour farming, etc. In addition to these, forage shrub plantations continue to be extensively promoted and established to rehabilitate degraded rangelands.

Bench terraces and earth or stone bunds drawn along contour lines, check dams, and hill lakes are among the most widely implemented structural techniques within the study area (Figure 2). A detailed review of the local scientific and technical literature related to these interventions was recently compiled by Zucca et al. (2015). The contour benches are earth embankments built perpendicular to the slope to intercept and store runoff water. They improve infiltration locally and reduce both the length of slope susceptible to runoff and the runoff velocity. They are increasingly built with earthmoving machines and are referred to as machine-made benches. Check dams made of gabions are installed on the stream beds to slow down the water flow and to improve infiltration into deeper soil and rock layers. The hill lakes are small earth dams located along the valley bottoms and at the depressions to collect runoff and to meet the local water needs, mainly for agriculture. In terms of "soft" conservation techniques within the study area, crop rotations and manuring practices predominate.

Data on physical achievements, e.g., in terms of total area treated with SWC structures, or lin-
Figure 2 - Mechanical bench terrace in Zoghmar (Sidi Bouzid, Central Tunisia). Photo taken in March 2015 by C. Zucca.

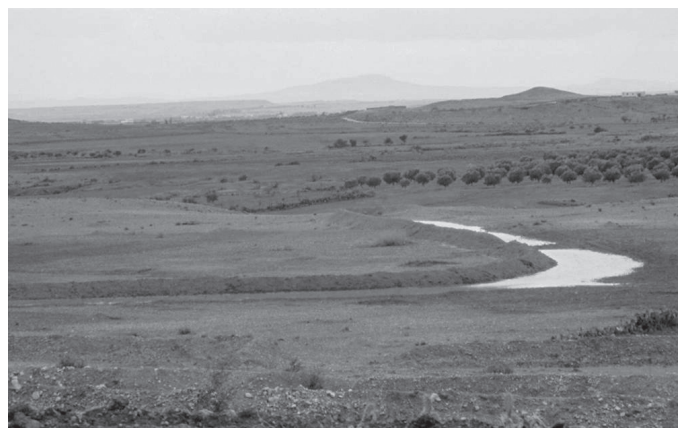

Source: Author's elaboration (2017).

ear length of benches and dams realized, or as number of dams or lakes, are not easily available for the study area. For this reason, and in order to obtain a better understanding of the intensity of SWC efforts conducted to date, a survey of the structures was undertaken through photo-interpretation of Google Earth imagery, as detailed within the following section.

\section{Geographical boundary}

This study was undertaken within two rural communities (Zoghmar and Selta) belonging to the governorate of Sidi Bouzid in central Tunisia (Figure 3). The governorate is of national importance to agricultural production, specifically in terms of area under production, as well as in relation to the existence of strong crop-livestock interactions. The study area occupies the north-western sector of the governorate, which is characterized by the mountains of the Jebel Mghilla range and by its piedmont landforms (glacis and alluvial plains). The elevation above sea level varies from more than $1,300 \mathrm{~m}$ to $400 \mathrm{~m}$, and slopes are often steep, causing widespread water erosion processes. The climate is semi-arid, with average annual rainfall of approximately $300 \mathrm{~mm}$. Land cover is characterized by degraded forest formation on the mountains, by alpha grass (Stipa tenacissima L.) steppe on the glacis slopes mainly used as pasture lands, and by annual croplands (cereals, forages and vegetable) and permanent crops (olive, almond and other fruit trees) on the alluvial 
Figure 3 - Location of the study area (rural communities of Zoghmar and Selta); Sidi Bouzid, Central Tunisia). A) Location map. B) Detail view.

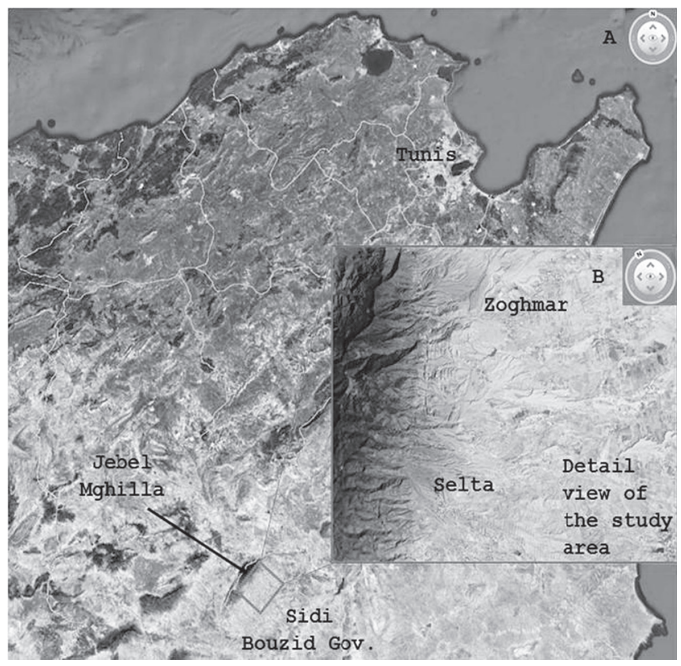

Source: Author's elaboration (2017).

areas. Pastures and cereals are by far the most important land uses, a characteristic feature of the cereal-sheep production system of central Tunisia.

The total area of the two rural communities is 12,390 ha. A survey of the SWC structures was conducted through photo-interpretation of Google Earth imagery for the Zoghmar rural community $(5,826 \mathrm{ha})$, revealing that to date a total of 1,552 ha $(26.6 \%)$ of land was subjected to interventions, of which around 1,340 ha with mechanical bench terraces, 122 ha with manual stone bunds, 89 ha with plantations (Hermassi T., personal communication; unpublished data). These data show that SWC interventions were conducted extensively in the study area indicating a high degree of exposure of the local population to this kind of practices.

\section{Methodological framework}

\subsection{Data sources and data analysis}

In employing a mixed methods design, data were collected through semi structured household interviews with analysis augmented through the collection and use of secondary sources of data. A multistage sampling technique was employed, with two regions (Zoghmar and Selta) selected in the first phase. In the second stage, eleven districts were randomly selected. Data were collected for the 2014-2015 cropping year from 250 producers (97 adopters and 153 non-adopters) located within the chosen regions. Data were compiled using SPSS (V.20) and analyzed using descriptive statistics, with econometric analyses undertaken for the purpose of comparing rates of adoption (and factors for adoption) between adopters and non-adopters.

\subsection{Analytical model}

Understanding the main determinants of SWCT adoption is a complicated process, similar to any other research on agricultural technology adoption (Adesina and Chianu, 2002), given the influence of a set of interrelated biophysical, socioeconomic, and institutional factors. Following Adesina and Zinnah (1992), the theory of utility maximization is widely used to explain farmers' response to the adoption of new technologies (Rahman and Huffman, 1984; Adesina and Zinnah, 1993; Bekele and Drake, 2003 and Asfawa and Admassie, 2004). According to this theory, new technology will only be adopted by a farmer if the utility gained out of its adoption exceeds the one associated with the existing and conventional technology.

Given that conventional regression analysis (Ordinary Least Squares or OLS) cannot accommodate missing observations for the dependent variable, Logistic Regression is utilized in order to predict a categorical (usually dichotomous) variable from a set of predictor variables. In our specific case, the objective of modelling is to predict an event that has two possible outcomes, adoption vs. non-adoption, thereby rendering the dependent variable as non-continuous, with only two possible values, 1 or 0 . This case violates the assumption of normal distribution (single peak), since a $1 / 0$ variable by definition is binomially distributed (double peak). The Binary Logistic Regression model addresses this problem by setting the predicted dependent variable as a function of the probability that a particular subject will be within one of the categories, i.e., by determining the odds of 1 or 0 . If the odds of 
1 are higher than the odds of 0 , then a 1 would be expected. This is accomplished by estimating the Log Odds Ratio, which is the log of the odds of 1 divided by the odds of 0 . Given that probabilities cannot take on negative values, the log of a positive number can have a value between negative infinity and positive infinity, thereby removing upper and lower bounds on the dependent variable, and allowing for estimation through a standard regression model.

Based on the approach described above, Binary Logistic Regression method (enabled to determine the impact of multiple independent variables on the dependent variable) was utilized

Table 1 - Description of the variables specified in the empirical binary logistic model $(\mathrm{N}=250)$.

\begin{tabular}{|c|c|c|c|c|}
\hline Acronym & Description & $\begin{array}{l}\text { Nature of the } \\
\text { variable }\end{array}$ & Type of measure & $\begin{array}{l}\text { Expected } \\
\text { Sign }\end{array}$ \\
\hline \multicolumn{5}{|c|}{ Dependent variables } \\
\hline ADOP & $\begin{array}{l}\text { Whether a farmer has } \\
\text { adopted (or not) SWC } \\
\text { technology }\end{array}$ & & Dummy ( 1 if yes, 0 if no) & \\
\hline \multicolumn{5}{|c|}{ Explanatory variables } \\
\hline AGE & Household head's age & Sociodemographic & Years & - \\
\hline EDUC & $\begin{array}{l}\text { Educational background } \\
\text { of the household head }\end{array}$ & Sociodemographic & $\begin{array}{l}\text { Dummy } \\
\text { ( } 1 \text { if the farmer accumulate more } \\
\text { than } 6 \text { years in education, } 0 \text { if less } \\
\text { than } 6 \text { years) }\end{array}$ & + \\
\hline FSIZ & $\begin{array}{l}\text { Number of people within } \\
\text { the household }\end{array}$ & Sociodemographic & Numbers (\#) & + \\
\hline FEXP & $\begin{array}{l}\text { Household head's farming } \\
\text { experience }\end{array}$ & Sociodemographic & Years (\#) & + \\
\hline LABE & Family labor force & Sociodemographic & Active labor force numbers (\#) & + \\
\hline TENUR & Status of land ownership & Sociodemographic & $\begin{array}{l}\text { Dummy } 1 \\
\text { ( } 1 \text { if fully owned; } 0 \text { otherwise) }\end{array}$ & + \\
\hline OFFA & $\begin{array}{l}\text { Farmer has an off-farm } \\
\text { income generating activity }\end{array}$ & Financial & Dummy ( 1 if yes, 0 if no) & $?$ \\
\hline CRED & Obtained credit / funding & Financial & Dummy ( 1 if yes, 0 if no) & + \\
\hline CBOS & $\begin{array}{l}\text { Member of a community } \\
\text { based organization } \\
\text { (CBO) / cooperative }\end{array}$ & Participation & Dummy ( 1 if yes, 0 if no) & + \\
\hline VLIVST & $\begin{array}{l}\text { Importance of livestock in } \\
\text { the farming system }\end{array}$ & Structural & $\begin{array}{l}\% \text { of livestock-related income in } \\
\text { total farm income }\end{array}$ & $?$ \\
\hline CONT & Contact with extension & Participation & $\begin{array}{l}\text { Estimated yearly number of visits } \\
\text { of extension agents to the farm (\#) }\end{array}$ & + \\
\hline CapBui & $\begin{array}{l}\text { Farmer attendance at } \\
\text { training meetings }\end{array}$ & Participation & Dummy (1 if yes, 0 if no) & + \\
\hline LFRA & Land fragmentation & Structural & $\begin{array}{l}\text { Number of plots owned divided } \\
\text { by total land area owned by the } \\
\text { farmer (\#) }\end{array}$ & - \\
\hline FSR & Stocking rate & Structural & $\begin{array}{l}\text { Flock size divided by total land } \\
\text { area owned by farmer }\end{array}$ & - \\
\hline
\end{tabular}

Source: Author's elaboration from field survey (2017). 
in order to regress the dependent variable (Y), which represents the choice of farmer adoption, against the factors affecting household head's adoption decision (He et al., 2007; Hall et al., 2009; Keelan et al., 2009) with:

$$
\mathrm{Y}=1 \text { : adopted SWCT; } 0 \text { : otherwise }
$$

Let $\mathrm{X}_{\mathrm{i}}$ represent the set of factors influencing the adoption decision of the $\mathrm{i}^{\text {th }}$ farmer. For the farmer, $Y_{i}$ is indirect utility derived from the adoption decision, a linear function of $\mathrm{k}$ explanatory variables $(\mathrm{X})$, and expressed by the following prediction equation:

$$
\begin{gathered}
\mathrm{Y}_{\mathrm{i}}=\ln \{\text { odds }(\text { event })\} \\
=\ln \{(\text { prob(event }) / \text { prob(nonevent })\} \\
=\ln \{(\text { prob }(\text { event }) / 1 \text {-prob(event })\}
\end{gathered}
$$

$=\operatorname{Ln}\left(\frac{P_{i}}{1-P_{i}}\right)=\operatorname{Ln}$ odds $=\beta_{0}+\sum_{i=1}^{n} \beta_{i} X_{k i}=Z_{i}$

$=\beta_{0}+\beta_{1} X_{1}+\beta_{1} X_{1}+\beta_{2} X_{2}+\cdots+\beta_{k} X_{k}$

Where $\tilde{Y}$ is the predicted probability of the event coded with 1 (adopt), $(1-\tilde{Y})$ is the predicted probability of the alternate decision (not to adopt), $\alpha$ is the intercept, and $X_{k}$ represents the following predictor variables (Table 1): AGE, EDUC, FSIZ, FEXP, LABE, TENUR, OFFA, CRED, CBOS, VLIVST, CONT, CapBui, LFRA, and FSR. $\beta_{1}, \beta_{2}, \beta_{3}, \ldots, \beta_{\mathrm{i}}$ are the coefficients associated with each explanatory variable $X_{1}$ to $X_{k i}$.

The model can therefore be expressed as follows:

$\mathrm{Y}=\alpha+\beta_{1} \mathrm{AGE}+\beta_{2} \mathrm{EDUC}+\beta_{3} \mathrm{FSIZ}+\beta_{4} \mathrm{FEXP}$

$+\beta_{5}$ LABE $+\beta_{6}$ TENUR $+\beta_{7}$ OFFA $+\beta_{8}$ CRED

$+\beta_{9}$ CBOS $+\beta_{10}$ VLIVST $+\beta_{11}$ CONT $+\beta_{12}$ CapBui

$+\beta_{13}$ LFRA $+\beta_{14}$ FSR $+\xi$

The above econometric model was estimated using an interactive maximum likelihood estimation procedure (Sidibé, 2005). This estimation procedure yields unbiased, efficient and constant parameter estimates.

\section{Results and discussion}

\subsection{Soil and water conservation practices within the study area}

Within the study area, improved soil and water conservation measures have historically been introduced through a range of national and international initiatives. Survey results indicate that the adoption of SWCT within the study area has been occurring since the 1980's. The most widely and intensively used techniques are generally physical and agronomic/biological practices (Table 2), with $16 \%$ and $26 \%$ of farm households practicing physical and agronomic conservation, respectively.

\subsection{Factors affecting adoption of SWCT with- in the study area}

A binary logistic regression model was fitted to estimate the effect of expected explanatory variables on the probability of a farmer being an adopter (or not) of SWCT. Fourteen explanatory variables (seven continuous and seven dummy) were included within the model. The summary data for the fourteen variables expected to affect adoption are presented in Table 3.

In order to test the existence of multi-collinearity, both continuous and discrete explanatory variables were checked using a Variance Inflation Factor (VIF). There would appear to be minimal correlation between the variables (Table 4). Based on this, all the explanatory variables were included within the final analysis.

The Maximum Likelihood method of Estimation (MLE) was used to draw parameter estimates from the binominal logistic regression model. Of the fourteen explanatory variables, four were found to be significant at less than or equal to ten percent probability level (farming experience, farmer membership within community based organization/cooperative, plot area, flock size). Table 5 shows the signs, magnitude and statistical significance of the estimated parameters and whether observed values were correctly predicted by the logistic regression model.

The likelihood ratio test statistic exceeds the Chi-square critical value with 15 degree of freedom. The result is significant at $(\mathrm{P}<0.01)$ 
Table 2 - Soil and water conservation practices in study area $(\mathrm{N}=250)$.

\begin{tabular}{|c|c|c|c|c|}
\hline \multirow[t]{2}{*}{$\begin{array}{c}\text { Soil and Water Conservation } \\
\text { Practices }\end{array}$} & \multicolumn{2}{|c|}{$\begin{array}{l}\text { Adopters - of at least } 1 \text { practice } \\
\qquad(\mathrm{N}=97)^{*}\end{array}$} & \multicolumn{2}{|c|}{ Non Adopters $(\mathrm{N}=153$} \\
\hline & $\mathrm{N}$ & $\%$ & $\mathrm{~N}$ & $\%$ \\
\hline \multicolumn{5}{|l|}{ Agronomic practices } \\
\hline Manuring & 16 & 6 & 234 & 94 \\
\hline Crop rotation & 47 & 19 & 203 & 81 \\
\hline Minimum tillage & 3 & 1 & 247 & 99 \\
\hline No tillage & 1 & 0 & 249 & 100 \\
\hline \multicolumn{5}{|l|}{ Physical structures } \\
\hline Terraces & 35 & 14 & 215 & 86 \\
\hline Soil bunds & 3 & 1 & 247 & 99 \\
\hline Stone bunds & 3 & 1 & 247 & 99 \\
\hline
\end{tabular}

Source: Author's elaboration from field survey (2017).

* 10 farmers adopt two different practices in at least one of their plots, and one farmer adopts three practices.

Table 3 - Summary of explanatory variables included in the logistic regression model ( $\mathrm{N}=250)$.

\begin{tabular}{|l|c|c|c|c|c|}
\hline \multicolumn{1}{|c|}{ Variables } & $\mathrm{N}$ & Minimum & Maximum & Mean & Std. Deviation \\
\hline ADOP & 250 & 0.00 & 1.00 & 0.38 & 0.48 \\
\hline AGE & 250 & 24.00 & 90.00 & 54.9 & 15.19 \\
\hline EDUC & 250 & 0.00 & 1.00 & 0.44 & 0.49 \\
\hline FSIZ & 250 & 1.00 & 30.00 & 6.40 & 2.98 \\
\hline FEXP & 250 & 2.00 & 75.00 & 31.1 & 15.61 \\
\hline LABE & 250 & 0.00 & 9.00 & 2.72 & 1.65 \\
\hline TENUR & 250 & 0.00 & 1.00 & 0.34 & 0.47 \\
\hline OFFA & 250 & 0.00 & 1.00 & 0.34 & 0.47 \\
\hline CRED & 250 & 0.00 & 1.00 & 0.08 & 0.27 \\
\hline CBOS & 250 & 0.00 & 1.00 & 0.07 & 0.26 \\
\hline VLVST & 250 & 0.00 & 1.00 & 0.65 & 0.29 \\
\hline CONT & 250 & 0.00 & 24.00 & 0.23 & 1.66 \\
\hline CapBui & 250 & 0.00 & 1.00 & 0.16 & 0.36 \\
\hline LFRA & 250 & 0.25 & 100.00 & 4.76 & 8.51 \\
\hline FSR & 250 & 0.00 & 6.10 & 0.53 & 0.68 \\
\hline
\end{tabular}

Source: Author's elaboration from field survey (2017).

probability level indicating that the hypothesis that all coefficients, with the exception of the intercept equal to zero is rejected. The results on the validity of the model using the Hosmer and Lemeshow statistic indicates a good fit of this model (as the significant value is 0.496 which is more than 0.05). This implies that we cannot reject the null hypothesis that there is no difference between the observed and predicted values of the dependent, implying that the model's estimates fit the data very well at an acceptable level of significance. The overall percentage of 
Table 4 - Variance Inflation Factor (VIF) for continuous explanatory variables $(\mathrm{N}=250)$.

\begin{tabular}{|l|c|c|}
\hline \multirow{2}{*}{ Variables } & \multicolumn{2}{|c|}{ Collinearity Statistics } \\
\cline { 2 - 3 } & Tolerance & $\begin{array}{c}\text { Variance Inflation } \\
\text { Factor (VIF) }\end{array}$ \\
\hline AGE & 0.378 & 2.646 \\
\hline EDUC & 0.868 & 1.152 \\
\hline FSIZ & 0.878 & 1.139 \\
\hline FEXP & 0.379 & 2.642 \\
\hline LABE & 0.940 & 1.064 \\
\hline TENUR & 0.794 & 1.260 \\
\hline OFFA & 0.743 & 1.346 \\
\hline CRED & 0.873 & 1.145 \\
\hline CBOS & 0.775 & 1.290 \\
\hline VLVST & 0.794 & 1.260 \\
\hline CONT & 0.777 & 1.287 \\
\hline CapBui & 0.846 & 1.182 \\
\hline LFRA & 0.927 & 1.079 \\
\hline FSR & 0.868 & 1.153 \\
\hline
\end{tabular}

Note: Dependent Variable: ADOP.

Source: Author's elaboration from field survey (2017).

correct predictions is $66.8 \%$. The column, Exp (B), in Table 5 provides the exponential of expected value of $\beta$ raised to the value of the logistic regression coefficient, which is the predicted change in odds for a unit increase in the corresponding explanatory variable.

The interpretation of the four significant explanatory variables is discussed below.

Farming Experience (FEXP): farming experience affects SWCT adoption positively and significantly at $(\mathrm{p}<0.1)$. The odds ratio of 1.021 indicates that, holding all other independent variables constant, the odds of adopting soil and water conservation technologies increases by a factor of 1.021 as farming experience of household head increases by one year. This result suggest that experience was possibly the most effective source of knowledge and consistent with the intuition that experience leads to familiarity and the generation of evidence of outcomes to support adoption. As soon as farmers started using these practices, they are more likely to continue practicing (Amsalu and Graaff,
2007). Therefore, farmers experience multiple knowledge barriers with respect to the adoption of such practices. Surveyed farmers lacked sufficient information about the benefits of these practices and how to perceive, use, and assess them, and many farmers felt underprepared to implement and optimize practices like crop rotation and terraces.

Farmer membership within CBO's/cooperative (CBOS): being a member of a community based organization (CBO) or cooperative affects the adoption decision of farmers positively and significantly at $(\mathrm{P}<0.01)$. This most likely indicates that $\mathrm{CBOS} /$ cooperative members support each other in the decision to adopt through a network of peers and through the exchange of personal knowledge on the benefits and costs to adoption. The value of the odds ratio was 5.311 indicating that by holding all other explanatory variables constant, each increase in the CBO score by one unit would generate an increase of the log-odds of adoption by 5.311 times. This suggest that the adoption of SWC practices within the study area is significantly influenced by the awareness of farmers to act within a cooperatives. Thus, increasing cooperative work efforts will certainly contribute to accelerate the adoption of SWC techniques.

Farmer attendance at training meetings (CapBui): The variable is significant at $(\mathrm{p}<0.05)$ and negatively related with SWCT adoption. The result is not consistent with the hypotheses that those farmers who have participated in trainings should have a higher probability to adopt such technologies. However, in this case, the indicator included all types of trainings, not only those specifically targeting SWCT. It is not clear, therefore, whether there were other competing technologies that were adopted or other compelling explanations for the negative coefficient. Equally important is a realization that this variable does not indicate the efficacy of training or the trainers. More specifically, the variable cannot gauge whether the trainings were too theoretical, too simple, and not practical in application, or whether the materials used in the training were not suitable to the local context. Further research is required in this regard to provide an explanation for this counter-intuitive result. 
Table 5 - Parameters estimates of the logistic regression model $(\mathrm{N}=250)$.

\begin{tabular}{|l|c|c|c|c|c|c|}
\hline \multicolumn{1}{|c|}{ Variables } & B & S.E. & Wald & D.f & Sig & Exp(B) \\
\hline AGE & $-0.019 \mathrm{NS}$ & 0.015 & 1.553 & 1 & 0.213 & 0.982 \\
\hline EDUC & $-0.038 \mathrm{NS}$ & 0.292 & 0.017 & 1 & 0.896 & 0.963 \\
\hline FSIZ & $-0.040 \mathrm{NS}$ & 0.049 & 0.646 & 1 & 0.421 & 0.961 \\
\hline FEXP & $0.021^{*}$ & 0.014 & 2.093 & 1 & 0.148 & 1.021 \\
\hline LABE & $-0.031 \mathrm{NS}$ & 0.083 & 0.138 & 1 & 0.710 & 0.969 \\
\hline TENUR & $-0.037 \mathrm{NS}$ & 0.315 & 0.013 & 1 & 0.908 & 0.964 \\
\hline OFFA & $-0.185 \mathrm{NS}$ & 0.321 & 0.331 & 1 & 0.565 & 0.831 \\
\hline CRED & $-0.389 \mathrm{NS}$ & 0.530 & 0.538 & 1 & 0.463 & 0.678 \\
\hline CBOS & $1.670^{* * *}$ & 0.635 & 6.914 & 1 & 0.009 & 5.311 \\
\hline CONT & $-0.004 \mathrm{NS}$ & 0.091 & 0.002 & 1 & 0.965 & 0.996 \\
\hline CapBui & $-0.790^{* *}$ & 0.439 & 3.245 & 1 & 0.072 & 0.454 \\
\hline LFRA & $0.002 \mathrm{NS}$ & 0.016 & 0.012 & 1 & 0.914 & 1.002 \\
\hline FSR & $0.222 \mathrm{NS}$ & 0.206 & 1.159 & 1 & 0.282 & 1.248 \\
\hline VLVST & $-1.016^{* *}$ & 0.515 & 3.896 & 1 & 0.048 & 0.362 \\
\hline Constant & $0.897 \mathrm{NS}$ & 0.812 & 1.221 & 1 & 0.269 & 2.453 \\
\hline
\end{tabular}

a. Variable(s) entered on step 1: AGE, EDUC, FSIZ, FEXP, LABE, TENUR, OFFA, CRED, CBOS, CONT, CapBui, LFRA, FSR, VLVST.
b. LR chi2(15)
85.844
c. Probability $>$ chi 2
0.0000
d. Overall \% of correct predictions
66.8
e. Log likelihood
308.078
f. Number of observations
250

g. *** Significant $1 \%, * * 5 \%$ and $* 10 \%$ probability level, NS $=$ not significant

Source: Author's elaboration from field survey (2017).

Livestock holding (VLVST): The variable is significant at $(\mathrm{p}<0.05)$ and related negatively with SWCT adoption. This negative trend has significant implications for adoption. Overgrazing is of significant concern in the study area. The observations that livestock producers would appear to be less keen to adopt conservation practices is consistent with the hypothesis that SWC technologies and conventional livestock rearing practices many not necessarily be compatible. The odds ratio of 0.362 suggests that, $c e-$ teris paribus, the odds ratio decreases by a factor of 0.362 as income from livestock (correlated with flock size) increases. One factor that may be relevant in explaining this result is competition for feed resources and trade-offs between the use of dry matter in conservation technologies and use in livestock feed. Equally important is the possibility for livestock grazing practices to interfere with the stability and sustainability of physical structures constructed for water harvesting and holding, which may be susceptible to damage from animals grazing on open pastures and rangelands if there is no guards in place or fences are not established to prevent livestock from entering fields where these technologies are implemented. Taken together, investments in physical infrastructure and existing traditional agricultural practices which embody tradeoffs in use may explain this negative correlation between livestock holdings and SWCT adoption.

The findings suggest that in the study area there is significant scope for improving agricultural sustainability and farmers' income through increased use of SWCT. Despite some level of existing adoption, findings indicate a need to 
provide adequate incentives, particularly technical assistance to farmers aimed at influencing the adoption of SWCT options.

\section{Concluding remarks and policy implica- tions}

Agricultural development in Tunisia is largely hampered by land degradation. Accelerated soil and water erosion is one of the major constraints threatening the overall sustainability of agricultural production where soil and water conservation is a highly-ranked priority within the country's development strategies. While numerous soil and water conservation technologies have been developed and promoted, adoption remains limited, and soil erosion continues to be problematic.

Results obtained from a survey of 250 farm households in the Central of Tunisia indicate that socio-economic conditions, livestock holdings, institutional factors, and some other biophysical factors significantly affect the probability that a farmer adopt both improved and traditional soil and water conservation measures. The adoption of introduced SWCT in the study area is positively influenced by the farming experience and farmer membership within CBO's. On the other hand, the farmer attendance at training meetings and the livestock holding by farmers have negatively influenced the adoption of introduced SWCT practices. On the other hand, age of the farmer, its education level, family size of household, contact with extension system, land tenure, family labor force, access to credit, and land fragmentation are not statistically significant in influencing the adoption of soil and water conservation practices. This suggest the promotion of cooperative work strategies among farmers who lack resources to perform SWC technologies, and the encouragement of information and experience exchange between farmers who have extensive experience with SWC technologies and those without experience. Moreover, such findings implies that SWCT policies that fail to account for inter household and inter plot variation, as well as important biophysical factors that influence the adoption of soil and water conservation measures by farmers are unlikely to be effective. This is of importance as it relates to the decision to adopt SWCTs for those farm households (and communities more generally) with strong crop-livestock production units.

Regardless of how beneficial a SWCT is, a one size fits all strategy for promoting and supporting a greater uptake of SWCT may not be effective if differences among production practices and land holdings are not considered. In addition, investment in physical soil and water conserving technologies appear to be more attractive on larger land holdings. This is likely a result of economics and of the pay back potential for investments in physical infrastructure. Access to capital, however, continues to be a vexing challenge and one where a programme for supporting uptake of SWCT must be tied to access to finance (working capital, lines of credit, as well as crop and livestock insurance) in order to foster greater uptake and attainment of desired environmental, economic and social outcomes.

The unexpected negative correlation between training and adoption remains unclear. This finding could be explained by a low efficacy, or low relevance, of the training provided. This indication should be evaluated by the local administrations. Extension and training services should be more targeted and possibly supported by the identification and use of opinion leaders within the community to promote SWCT. Aside from this endorsement, the establishment and maintain of demonstration farms and areas, where the benefits of the promoted SWC practices could be shown, and the feasibility of incorporating farmer-specific biophysical, hydro-climatic and socio-economic conditions could be assessed with the farmers' participation, would rise awareness of SWCTs.

To increase exposure of SWCTs and maximize outreach, more participatory and inclusive systems of innovation are likely to assist in ensuring that contextual relevance is embodied within trainings and policies for sustainable land use management. Local institutions are critical in this regard, particularly in the MENA (Middle East and North Africa) region, where cooperatives and community based organizations can provide their members with an arena (or a 
platform) for sharing experiences jointly identifying avenues to address shared challenges, and thereby supporting each other in the decision to adopt SWCTs, either collectively or individually, through participatory knowledge generation.

\section{Acknowledgments}

This work was undertaken as part of, and funded by, the CGIAR Research Program on Dryland Systems (http://drylandsystems.cgiar.org/) led by the International Center for Agricultural Research in the Dry Areas (ICARDA: http://www. icarda.org). The authors are also grateful to the Food and Agriculture Organization of the UN (FAO), under a non-numbered grant agreement to ICARDA, within the water scarcity initiative of the Near East and North Africa. The opinions expressed here belong to the authors, and do not necessarily reflect those of Dryland Systems, ICARDA, FAO or CGIAR.

\section{References}

Abdulai A., Owusu V., Bakang J.E.A., 2011. Adoption of safer irrigation technologies and cropping patterns: Evidence from Southern Ghana. Ecological Economics, 70: 1415-1423.

Achouri M., 1995. La conservation des eaux et du sol en Tunisie: bilan et perspectives. In: Zekri S., Laajimi A. (eds.), Agriculture, durabilité et environnement. Cahiers Options Méditerranéennes, 9: 35-47. CIHEAM, Zaragoza.

Adesina A.A., Zinnah M.M., 1992. Explaining smallholder farmer adoption process: an alternative using tobit analysis of rice farmers' decisions in Sierra Leone. Adoption and Impact Assessment Reports. ADRAO, M'be.

Adesina A.A., Zinnah M.M., 1993. Technology characteristics, farmer's perceptions and adoption decisions: a tobit model application Sierra Leone. Agricultural Economics, 9: 297-311.

Adesina A.A., Chianu J., 2002. Determinants of farmers' adoption and adaptation of alley farming technology in Nigeria. Agroforesty Systems, 55: 99-112.

Alcon F., De Miguel M.D., Burton M., 2011. Duration analysis of adoption of drip irrigation technology in southeastern Spain. Technological Forecasting \& Social Change, 78: 991-1001.

Amsalu A., De Graaff J., 2007. Determinants of adoption and continued use of stone terraces for soil and water conservation in an Ethiopian highland watershed. Ecological Economics, 61: 294-302.

Asfawa A., Admassie A., 2004. The role of education on the adoption of chemical fertilizer under different Socio-economic environments in Ethiopia. $\mathrm{Ag}$ ricultural Economics, 30: 215-228.

Bachta M.S., 1995. Conservation des Eaux et du Sol (CES) en Tunisie. Intervention des pouvoirs publics et stratégies paysannes: un éclairage économique. In: Zekri S., Laajimi A. (eds.), Agriculture, durabilité et environnement. Cahiers Options Méditerranéennes, 9: 35-47. CIHEAM, Zaragoza.

Baumgart-Getz A., Stalker Prokopy L., Floress K., 2012. Why farmers adopt best management practice in the United States: A meta-analysis of the adoption literature. Journal of Environmental Management, 96: 17-25.

Bekele W., Drake L., 2003. Soil and water conservation decision behavior of subsistence farmers in the Eastern Highlands of Ethiopia: a case study of the Hunde-Lafto area. Ecological Economics, 46: 437-451.

CNEA - CRDA du Sidi Bouzid, 1994. Etude du projet de développement agricole intégré du Nord et Nord-Est du gouvernorat du Sidi Bouzid. Centre national des études agricoles et Commissariat du Développement Agricole.

CNEA, 2007. Etude stratégique sur le Développement durable et agriculture dans les cinq gouvernorats de Gabès, Sidi Bouzid, Nabeul, Le Kef et Bizerte. Rapport final de la 1ère Phase. Centre national des études agricoles, Tunis.

CNEA, 2008. Etude sur l'état de la désertification pour une gestion durable des RN en Tunisie. Rapport de la troisième phase. Centre national des études agricoles, Tunis.

CRDA Sidi Bouzid, 2003. Projet de développement agricole intégré du Nord et Nord-Est du gouvernorat du Sidi Bouzid. Commissariat du Développement Agricole.

Cooly L., Linn J.F., 2014. Taking innovations to scale: Methods, applications and lessons. Results for Development Institute/Management Systems International, Washington DC.

De Graaff J., Amsalu A., Bodnar F., et al., 2008. Factors influencing adoption and continued use of long-term soil and water conservation measures in five developing countries. Applied Geography, 28: 271-280.

FAO, 2011. The State of the World's Land and Water Resources for Food and Agriculture (SOLAW) - Managing Systems at Risk, Food and Agriculture Organization of the United Nations, Rome, Italy. London: Earthscan. 
Hall T.J., Dennis J.H., Lopez R.G., Marshall M.I., 2009. Factors affecting growers' willingness to adopt sustainable floriculture practices. Horticulture Science, 44: 1346-1351.

He X.F., Cao H., Li F.M., 2007. Econometric analysis of the determinants of adoption of rainwater harvesting and supplementary irrigation technology (RHSIT) in the semiarid Loess Plateau of China. Agricultural Water Management, 89: 243-250.

Heusch B., 1986. Cinquante ans de banquettes de DRS-CES en Afrique du Nord. Un bilan. DG ACTA, Tunis.

Hudson N.W., 1993. Les raisons du succès ou de l'échec des projets de conservation des eaux et des sols. DG ACTA, Tunis.

Jara-Rojas R., Bravo-Ureta B.E., Engler A., Diaz J., 2013. An analysis of the joint adoption of water conservation and soil conservation in Central Chile. Land Use Policy, 32: 292-301.

Karaa E., Ribaudob M., Johansson R.C., 2008. On how environmental stringency influences adoption of best management practices in agriculture. Journal of Environmental Management, 88: 1530-1537.

Khanna M., Epough O.F., Hornbaker R., 1999. Site-specific crop management: Adoption patterns and incentives. Review of Agricultural Economics, 21: 455-472.

Keelan C., Thorne F.S., Flanagan P.L., et al., 2009. Predicted willingness of Irish farmers to Adopt GM Technology. AgBioForum, 12: 394-403.

König H.J., Sghaier M., Schuler J., et al., 2012. Participatory impact assessment of soil and water conservation scenarios in Oum Zessar watershed, Tunisia. Environmental Management, 50: 153-165.

Lapar M., Lucila A., Pandey S., 1999. Adoption of soil conservation: the case of Philippine uplands. Agricultural Economics, 21: 241-256.

Marques M.J., Schwilch G., Lauterburg N., et al., 2016. Multifaceted Impacts of Sustainable Land Management in Drylands; a Review. Sustainability, 8(2): 177.

MEHAT 2009. Schéma directeur d'aménagement de la région économique du centre-ouest. Ministère de l'Equipement, de l'Habitat et de L'Aménagement du territoire. Direction Générale de l'Aménagement du Territoire. Tunis, $239 \mathrm{p}$.
Menozzi D., Fiorvanzi M., Donati M., 2014. Farmer's motivation to adopt sustainable agricultural practices. BAE Bio based and Applied Economics, 4(2): 125-147.

MoA - Ministry of Agriculture, 2014. Revue sectorielle de l'eau en Tunisie. Bureau de planification et des équilibres hydrauliques, $72 \mathrm{p}$.

Ouessar M., Yahyaoui H., Belgacem A.O., et al., 2006. Aménagements et techniques de lutte contre la désertification: Inventaire et bilan. In: Genin D., Guillaume H., Ouessar M., Belgacem A.O., Romagny B., Sghaier M., Taamallah H. (eds), Entre la désertification et le développement: la Jeffara tunisienne. CERES, Tunis, 147-161.

Rahm M.R., Huffman W.E., 1984. The adoption of reduced tillage: the role of human capital and other variables. American Journal of Agricultural Economics, 66: 405-413.

Robinson J.R., Napier T.L., 2002. Adoption of nutrient management techniques to reduce hypoxia in the Gulf of Mexico. Agricultural Systems, 72: 197213.

Roose E., Sabir M., Arabi M., et al., 2012. Soixante années de recherches en coopération sur l'érosion hydrique et la lutte antiérosive au Maghreb. Géographie Physique et Environnement, 6: 43-69.

Sghaier M., Mahdhi N., De Graaff J., et al., 2002. Economic assessment of soil and water conservation works: case of the wadi Oum Zessar watershed in south-eastern Tunisia. In: De Graaff J., Ouessar M. (eds.), Water harvesting in Mediterranean zones: an impact assessment and economic evaluation, TRMP paper 40, 101-113. The Netherlands: Wageningen University.

Sidibé M., 2005. Farm-level adoption of soil and water conservation techniques in northern Burkina Faso. Agricultural Water Management, 71: 211224.

Soule M., Tegene A., Wiebe K., 2000. Land tenure and the adoption of conservation practices. American Journal of Agricultural Economics, 4: 9931005.

Zucca C., Hermassi T., Ouessar M., et al., 2015. Impacts of soil and water conservation techniques in Tunisia. Inventory of research works and studies. ICARDA. CGIAR. Technical report, $45 \mathrm{p}$. 